\title{
The Role of Innovation Characteristic Toward Adoption Intention of E-Paper Product
}

\author{
Sholahuddin ${ }^{1}$, Anton A. Setyawan ${ }^{2}$, Rina Trisnawati ${ }^{3}$ \\ Koran Solo Pos1, Solo, Indonesia ${ }^{1}$ \\ Fakultas Ekonomi dan Bisnis, Universitas Muhammadiyah Surakarta, Indonesia ${ }^{2,3}$ \\ sholahuddin.mz@gmail.com ${ }^{1}$, anton.setyawan@ums.ac.id ${ }^{2}$,rina.trisnawati@ums.ac.id ${ }^{3}$
}

\begin{abstract}
This paper to examines factors that the influence of innovation characteristic to intention to adopt Solopos epaper. Nowdays, many newspaper companies in Indonesia to offer the electronic paper (epaper) services. But not many studies that analyze the factors that might help the industry of epaper for designing epaper services. This research will to fill the lack of studies on the epaper phenomena. This study investigated the factors that influence the intention to adopt Solopos epaper. Using the Diffusion of Innovations and Technology Acceptance Model (TAM) as the baseline theory, this research involved 103 respondents from local newspaper readers. Research shows that relative advantage and observability have positive impact to intention to adopt epaper. And then, compatibility, compexity, and trialability don't have positive impact to intention to adopt epaper. The result of this research is usefull for developing electronic newspaper industry in Indonesia.
\end{abstract}

Keywords: Characteristic of Innovations, Diffusion of Innovations, Intention to Adopt, E-paper.

\section{Introduction}

Diffusion of innovation theory is developed by Everett M Rogers, reviews the innovation decisions. In Diffusion of Innovation (DOI) the diffusion of innovation concept along with the speed of a social system in accepting new ideas from an innovation[1]. Many researchers refer Roger's theory to this day in particular to discuss the diffusion of innovation issues.

Rogers' diffusion of innovation research is best known and widely respected[2]. Rogers studied nearly 4,000 diffusion publications to revise previous theories about the innovation decision process. This was a huge improvement in diffusion research at that time.

The researcher is interested in using the Rogers' theory perspective on the characteristics of innovation to explain consumer intentions of Solopos print edition to adopt the Solopos e-paper[1]. Solopos is a local newspaper published in Solo City, Central Java, Indonesia. 
There are three basic concepts on Rogers' DOI including innovation, diffusion and adoption. Innovation is a thought, implementation or perceived object as something new in the eyes of everyone. Diffusion is way toward imparting an innovation through a communication channel and within a certain time to members of the social system. Adoption happens on the grounds that individuals completely use an innovation into practice as the best choice [1]. defines the adoption of innovation as a mental process by individuals through the first stage in studying innovation toward final adoption[3].

With regards to the diffusion of innovation toward final adoption, offers attributes that reduce the uncertainty of innovation that affects a person's adoption rate of new products[1]. In Rogers' perspective the characteristics of this innovation affect the rate of adoption in individuals and consumers. Rate of adoption is the relative speed of an innovation to be adopted by members of the social system.

The first characteristic of innovation is the relative advantage or the level of an innovation perceived better than the previous innovation idea. Second is compatibility or the degree of perceived innovation in accordance with prevailing values, past experiences and conformity to the needs of potential potential adopters. Third, the complexity that constitutes the perceived level of innovation is difficult to understand or use. Fourth, trialability is the degree of innovation or experimented of an inovation on a limited scope. Fifth, observability that refers to degree of innovation visibility for others.

The five characteristics of innovation according to that 'persuasion stage' plays an important role in innovation decisions[1]. If an innovation simultaneously excels relatively, in accordance with previous values and habits, uncomplicated, pilotable and renewable, then the innovation will be quickly adopted by both individuals and social systems.

The theory of TAM by Fred D. Davis is useful for explaining the behavioral intention in this study. Behavioral intention is a tendency to react and an important factor for predicting consumer behavior[4]. Behavioral Intention describes a person's behavior and attitude in using a system influenced by two factors including percieved usefullness and percieved of use. Behavioral intention in this study is interpreted as a person's tendency to react in determining full adoption of an innovation as the best choice.

Researchers are interested in using a framework of innovation characteristics to predict the behavioral intention of readers of Solopos Daily print edition to adopt Solopos Epaper or Solopos electronics. Epaper is a newspaper with the same layout and content as the print edition but physically is a digital medium propagated over the internet network. This epaper product is unique because it has a conventional media content but in terms of products and ways of providing to consumers, epaper including new media. Epaper was first introduced in 1995 [5]. Solopos epaper itself was launched in 2015 through the site www.epaper.solopos.com, and this could be said as a new product.

Several previous studies have demonstrated Rogers' innovative characteristics that greatly influence consumers in adopting innovative products. The relative advantage positively influenced the decisions of war veteran members in adopting e-government services[6].

An influence on the intention of using groupware (group conversation to work) for the benefit of the organization[7]. Complexity positively affects the intention of adopting mobile marketing in Malaysia[3]. The trialability had an effect on the intention of using a groupware application to 
support organizational work[7]. The observability had a positive effect on the intention of using an online learning system of company employees in Taiwan[4].

Currently, newspaper managers must think hard to keep their business line up. The new findings about information technology have influenced many things. Technological changes in the mass media industry not only change channels or mediums in disseminating information, but also change the way people consume news. During this time the dissemination of information is identical to paper, either through newspapers or magazines. The words "news" and "paper" seem to be two words that can not be separated. The idea of the newspaper itself is as old as the ancient Romans.

Daily events were published through scrolls called Acta Durna or "daily activities". That was the first newspaper anyone ever made. Newspapers gained popularity and grew rapidly after John Gutenburg invented the printing press in 1450 . For more than 500 years the paper then became the most efficient medium of information dissemination, data and documents judged [8].

Technology in the virtual world is now transformed into a new channel of public information delivery. Not surprisingly, many newspapers now use internet technology to spread to consumers.

Transformation from print to digital by media companies is done in various ways. In addition to building news sites that are running news (news is always updated at any time), the newspaper company also launched a newspaper in digital version or electronic newspaper (epaper). This shows the potential market of internet users continue to rise.

In this connection the researchers wanted to analyze whether Rogers's innovation characteristics were influential in his intentions to adopt Solopos epaper among readers of the Solopos newspaper. In previous studies the characteristics of innovation had an effect on the intention of adopting a system, but was it also applicable in the case of the intention of adopting an electronic newspaper? Based on the exposure in the background of the problem, the problem formulation in this research is, whether the characteristics of innovation such as relative advantage, compatibility, complexity, trialbility, and observability have an effect on the intention to adopt Solopos epaper newspaper?

\section{Method}

This study uses a quantitative approach emphasizes on hypothesis testing of precise variables. This study looks for causal relationships or causal relationships. In this study there are independent and dependent variable or variable[9]. Data were collected through a structured questionnaire in which each variable was measured by a likert scale of 1-5. Number 5 indicates "very agree", 4 (agree), 3 (neutral), 2 disagree, 1 (very disagree).

\subsection{Population and Samples}

The population in this study covers all readers of local and national newspaper as well as internet accessers in several cities in Indonesia. Non-random samples were taken by purposive sampling or sampling technique based on certain considerations [9]. The consideration in this study is the Solopos reader sample who reads this newspaper on average three times a week in the past month during the study. Samples are also internet users at least three times a week in the last month.

The sample size is feasible in a study between 30-500 samples. While in the mutivariate study (including multiple regression analysis) the sample size averaged 10 times or more from the number of variables used in the study [10]. There are two main characteristics of a research sample: efficiency and representation[10]. 
Based on that opinion, the researcher decided to take sample size as much as 20 times the number of variables $(20 \times 6)=120$. While from 120 questionnaires only 103 can be analyzed because of various considerations. This amount has met the rules of representation and efficiency (time, effort and cost) in the implementation of this research.

The data used in this study is primary data collected through a questionnaire instrument tersturktur. Data were collected from May to June 2016. Data analysis used to find the causality relationship using multiple linear regression. Regression is used to determine the effect of independent variables on the dependent variable.

\subsection{Empirical Model}

Characteristic of innovation is the characteristic that will determine the level of one's adoption of innovation, which consists of five characteristics including advantages, compatibility, complexity, triability, and observability. Each of these characteristics will be an independent variable in this study[1].

Relative Advantage: the refers to the degree or degree of an innovation perceived to be better than the idea of previous innovations or those of counter-ideas[1]. Relative advantage can be measured in economic terminology, but social prestige, convenience, and satisfaction factors are often equally important components. Stated that relative advantage can be measured through work more quickly, Job performance, Increase productivity, effectiveness, efficiency, and makes job easier [11].

Compatibility: compatibility is the degree of an innovation perceived consistently with existing values, past experiences, and according to the needs of potential people as adopters[1]. This concept refers to an innovative rate of innovative product innovation adoption if consumers feel the same values or beliefs offered by innovative products[11]. attributes of conformity include fit with existing ways of doing things, fit with prevailing value and fit experience, and fit with belief [11].

Complexity the degree to which an innovation is perceived as difficult to understand or use, and it is assumed to be negatively related to the adoption and implementation of innovation[1]. Instruments proposed indicators for measuring complexity including easy to learn clear and understandable, easy to become skillful, easy to use, controllable and flexibel[11].

Trialability refers to the degree to which an innovation can be experimented on a finite scope [1]. In theory, innovations that can be tried on a limited scope will be adopted and implemented more frequently and faster than less-implemented innovations[1]. Experiments can be measured using indicators to be able to try out a new product and to find out how it works under one's own condition[11].

Observability is the level of an innovation that makes it visible to others [1]. The result of an innovation that is increasingly easier to see by individuals, the more likely it is to adopt. Innovation will be high if consumers find it easy to find the benefits or attributes of innovative products offered [1];[11]. The measure the attributes of visibility with Easily observed and communicated to others and the other person models how to innovations works as well as the benefits of use[11]. 
Table 1. Independent Variable Indicators[11]

\begin{tabular}{ll}
\hline Variables & Indicators \\
\hline Relatif Advantage & Economic Benefits \\
& Comfortable in Use \\
& Prestige \\
Work Faster & Work Easier \\
Compatibility & Compatibility with the way people do things right \\
& now \\
& Conformity with past values and experiences \\
& Conformity with the belief of the adopter \\
Complexity & Easy to learn \\
& Easy to understand \\
& Easy to use \\
& Flexible \\
Trialability & Can be tried \\
& Easy to find how to use \\
& Easy to observe \\
Observability & Ease to communicate to others \\
& Other people can feel the benefits \\
\hline &
\end{tabular}

Dependent variable in this research is intention to adopt. Behavioral intention is a person's tendency to act and becomes an important factor in predicting consumer behavior[4]. Adoption takes place when the individual has a positive evaluation of an innovation and then receives fully innovation as the best choice of the various options available[1]. The intention to adopt is a person's tendency to act in determining the adoption of epaper as the best option.

Table 2. Dependent Variable Indicators[1]

\begin{tabular}{cl}
\hline \multicolumn{1}{c}{ Variable } & Indicators \\
\hline \multicolumn{1}{c}{ Intention } & Positive \\
to Adopt & Perceptions \\
& Intention to \\
& use \\
& When to \\
& adopt \\
\hline
\end{tabular}

Source:[1];[4];[12]

The linear regression equation of the model as follows:

$\mathrm{Y}=4,329+0,182 \mathrm{X} 1+0,073 \mathrm{X} 2+0,127 \mathrm{X} 3-0,01 \mathrm{X} 4+0,246 \mathrm{X} 5+\mathrm{e}$ 
1). The value of the constant is 4.239 , which means that the performance of variable $Y$ (intention to adopt) of 4,239 when the independent variable performance relative advantage, compatibility, complexity, trialability, and observability is zero $(0)$.

2 ). The positive value coefficient of relative advantage ( $\beta 1)$ value of 0.183 indicates that the relative advantage of high Solopos epaper will increase the behavior of the intention to adopt Solopos epaper.

3). Coefficient value of positive compatibility ( $\beta 2$ ) positive equal to 0,073 which indicate when value of variable compatibility Solopos epaper rise, hence will influence to increase of value at variable of intention to adopt Solopos epaper. If Solopos epaper is more in line with the values adopted as well as previous habits, it will increase the behavior of the intention to adopt the Solopos epaper.

4). The coefficient value of the complexity ( $\beta 3$ ) variable is positive value of 0.127 which indicates an increase in the value of the complexity variable-in this case the inelasticity-using Solopos epaper will increase the variable value of the intention of adopting the Solopos epaper. The simpler and easier Solopos epaper is used, the greater the behavior of the intention to adopt the Solopos epaper.

5). The value of variable coefficient of trialability ( $\beta 4$ ) is negative $-0,001$ which means that the value of trialability variable will decrease the behavior of the intention to adopt Solopos epaper.

$6)$. The value of observability variable coefficient $(\beta 5)$ is positive value 0.246 which indicates the increase of observability variable value (visibility) how to use Solopos epaper will influence to increase behavior of intention to adopt Solopos epaper.

\section{Result}

The validity test of Corrected Item-Total Correlatio to 24 question items in the questionnaire to measure the variables in this study has a correlation coefficient greater than the value of $r$ table> 0.256 , where $n=103$ at the significance level of $1 \%$, indicating the validity of all question items. The reliabilias test of 24 questionnaire items concluded the reliability due to the value of cronbach alpha> 0.6..The normality test using kolmogorof-smirnof shows 0.895 or above the $p$ value of 0.05 , indicating normal distributed data. The multicolorarity test can be seen from the variance inflation factor (VIF). The tolerance limit value $<1$ or the VIF value is greater than 10 . The test results indicate that all independent variables of the VIF value are less than 10 and the tolerance value is greater than 1 so there is no deviation of classic multicoloniality assumptions between the variables in the model.

Heteroskedasticity test with glejser-test which is data test by regressing residual absolute value against independent variable. With significance of $\mathrm{t}$ value $>0,05$, hence there is no heteroscedasticity. The test result shows the $t$ test value of all independent variables is above 0.05 , so it can be concluded there is no heteroscedasticity.

Multiple linear regression analysis is useful to find the influence of independent variables (relative advantage, compatibility, complexity, trialability, observability) to the dependent variable (intention to adopt). 
Table 3. Result of Multiple Linear Regression Analisys

\begin{tabular}{lcccc}
\hline $\begin{array}{l}\text { Independent } \\
\text { Variables }\end{array}$ & $\begin{array}{c}\text { Regression } \\
\text { Coefficient }\end{array}$ & t statistic & Sig & Description \\
\hline Constants & 4,329 & 2,478 & 0,015 & - \\
Relative Advantage & 0,182 & 2,192 & 0,031 & Significant \\
Compatibility & 0,073 & 0,880 & 0,381 & Not Significant \\
Complexity & 0,127 & 1,121 & 0,265 & Not Significant \\
Trialability & $-0,001$ & $-0,012$ & 0,991 & Not Significant \\
Observability & 0,246 & 2,021 & 0,046 & Significant \\
\hline
\end{tabular}

\begin{tabular}{ll}
\hline $\mathrm{R}$ & $=0,478$ \\
$\mathrm{R}-$ Square & $=0,229$ \\
F-Count & $=5,7$
\end{tabular}

\section{Discussion}

\subsection{The influence of relative advantage on the intention of adopting e paper}

The test results showed the influence of the relative advantage variable on the intention to adopt epaper. This reality shows the relative advantage of Solopos epaper perceived better than previous innovation ideas, and has an effect on the intention of adopting Solopos epaper.

'Percieve relative advantage' on high Solopos epaper increases the chances of intending to adopt the epaper. The effect of the relative superiority to the intention of adopting this is because respondents perceive epaper to offer many advantages over print edition. Some advantages of using epaper instead of print, in this study, among others, using epaper is cheaper than the print edition, comfortable, and more prestigious than the printed edition.

These results show the hypothesis of the effect of relative advantage on the intention of adopting epaper. The results of this test are in harmony with Rogers's theory of the diffusion of innovation and the behavioral theory intention of Fred D. Davis used in this study. Study shows that relative advantage influences the intention of adopting mobile marketing in Malasyia[3].

\subsection{The influence of compatibility on the intention of adopting e paper}

The results of the tests in this study showed that compatiblity had no significant effect on the intention of adopting epaper. Compatibility is the level of an innovation perceived consistently with existing values, past experiences, and according to the needs of potential people as adopters. An idea that is inconsistent with the values and norms within a social system, will not be adopted as quickly as such as appropriate innovation [1].

In this study the conformity factors are, among others, measured by the similarity of content between epaper and printed edition, the equality of information received by readers. There are also similar habitual factor between reading epaper with print, as well as the same habit between accessing epaper with the habit of accessing the internet. These results indicating the foregoing is not a factor affecting readers of printed newspapers to have intention to adopt the Solopos epaper. Not influencing variable suitability of intentions to adopt this is very likely because respondents rated Solopos epaper not in accordance with their customs in reading the contents of newspapers print edition. 
The results of this hypothesis test show that it is not in accordance with or contrary to the results of previous research which states that the variable compatibility has an effect on the behavior of the intention to adopt the innovation. Compatibility to influence the intention of adopting groupware applications for the benefit of the organization[7]. Compatibility positively affected the intention of using online learning system in Taiwan[4].

\subsection{The influence of complexity on the intention of adopting e paper}

The hypothesis test of this research shows that the complexity variable has no significant effect on the intention to adopt Solopos epaper. Complexity is the degree to which an innovation is perceived as difficult to understand or use[1]. The more complex the results of innovation, the smaller the innovation will be adopted. Conversely easier and simpler results of innovation, the easier it is also accepted by consumers. In this study the complexity is measured from easy to learn clear and understandable, easy to use, and flexibel. The easier an innovation to learn and use, the easier it is to adopt.

Some aspects of complexity measured in this study include the ease of using epaper, the content of Solopos epaper is easy to understand, easy to use, and the use of flexible Solopos epaper because it can be opened anywhere as long as there is internet network. However, the results of this study indicate the convenience factors, the simplicity of the use of Solopos epaper has no effect on Solopos customers to intend to adopt Solopos epaper.

Accessing the Solopos epaper is still seen as complicated rather than accessing Solopos print edition, thus preventing them from intending to adopt the Solopos epaper. The results of this hypothesis test are not aligned with the results of previous studies. Concluded that complexity influences the intention of adopting mobile marketing in Malaysia[3]. Complexity negatively affecting the intention of using e-government services of war veterans[6].

\subsection{The influence of trialability on the intention of adopting e paper}

The hypothesis test showed that the variable of trialability had no significant effect on the intention of adopting Solopos epaper. Trialability is the degree to which an innovation can be experimented or tested on a limited scope [1]. In theory, innovations that can be tried will be adopted and implemented more frequently and faster than less-implemented innovations[1].

In this study, trialability was measured by several indicators, including attempting previous Solopos epaper, Solopos epaper providing product samples, Solopos epaper providing information on how to use, as well as easy to learn instructions on using Solopos epaper.

From these indicators there is no effect on readers of Solopos print edition intending to adopt Solopos epaper. From some indicators of the experiment many respondents who do not know Solopos epaper can be tested. PT. The script of Solopos has not yet maximally promoted the Solopos epaper by giving the facility a wide range of prospective customers to try Solopos epaper.

The results of this hypothesis test contradict the results of previous research that became a reference in this study. Trialability had an effect on the intention of using a groupware application (technology designed to facilitate group work) for the benefit of the organization[7]. Trialability positively affected the intention of using an online learning system in Taiwan[4]. 


\subsection{The influence of observability on the intention of adopting e paper}

Hypothesis test showed that the observability variable had an effect on the intention to adopt Solopos epaper. Observability is the level at which an innovation is visible to others. The results of an innovation are easy to see, increasing the likelihood of individuals adopting the innovation [1].

In this study observability is measured from several indicators, including the ease of viewing the use of Solopos epaper, easy-to-communicate Solopos epaper usage instructions, and easy-to-see examples of Solopos epaper products.

From these indicators, the results of the tests in this study, these factors have an effect on the intention of adopting Solopos print consumer to adopt Solopos epaper. This means that some guidelines on the use of the Solopos epaper are favorable, thus influencing them to intend to adopt the Solopos epaper. The result of this hypothesis test is consistent with the previous researches used in this study which states that observability has an effect on the intention to adopt innovation. Observability to affect the intention of using online learning system in Taiwan[4].

\section{Conclusion}

The statistical tests of five independent variables include relative advantage, compatibility, complexity, trialability, observability of the dependent variable (intention to adopt: 1) Relative advantage variables affect the intention to adopt Solopos epaper. This means that the relative advantages of Solopos epaper resulted in the intention to adopt Solopos epaper as a replacement reading of Solopos print edition. 2) Compatibility variable has no effect on the intention to adopt Solopos epaper. Several indicators in conformity variables such as the content similarity between Solopos epaper and Solopos print, the equality of information received, the same custom between accessing Solopos epaper with Solopos prints has no significant effect on people's intentions to adopt Solopos epaper. 3) Complexity variable has no effect on the intention to adopt Solopos epaper. This means that the ease factor for accessing Solopos epaper has no effect on the intention of adopting Solopos epaper. 4)Trialability variable has no effect on the intention to adopt Solopos epaper. This means that the existing trials in Solopos epaper can not immediately affect the intention to adopt the Solopos epaper.5) Observability variable gives influence to the intention to adopt Solopos epaper. This means that the higher level of observability (visibility) will further increase the chances to grow the intention to adopt Solopos epaper.

\section{References}

[1] S. Schönborn, "59. Everett M. Rogers, Diffusion of Innovations," dalam Schlüsselwerke der Kulturwissenschaften, transcript Verlag.

[2] M. S. Yuliarti, "Agama dan Entertainment: Fungsi Sosial Media Massa Dalam Program Religi di Tv," J. Komun., vol. 5, no. 2, hlm. 101-108, Apr 2011.

[3] G. H. Tanakinjal, and K. R. Deans, B. J. Gray, dan and, "Intention to Adopt Mobile Marketing: An Exploratory Study in Labuan, Malaysia," Asian J. Bus. Res., vol. 1, no. 1, Mar 2011.

[4] Z.-H. Sun, "Information System and Management Strategy of Customer Relationship Management," dalam 2008 3rd International Conference on Innovative Computing Information and Control, 2008. 
[5] A. C. Cooper dan D. Schendel, "Strategic Responses To Technological Threats," Bus. Horiz, vol. 19, no. 1, hlm. 61-69, Feb 1976.

[6] A. Lawson-Body, A. Illia, L. Willoughby, dan S. Lee, "Innovation Characteristics Influencing Veteransitextquotesingle Adoption of E-Government Services," J. Comput. Inf. Syst., vol. 54, no. 3, hlm. 34-44, Mar 2014.

[7] C. V. Slyke, H. Lou, dan J. Day, "The Impact of Perceived Innovation Characteristics on Intention to Use Groupware," Inf. Resour. Manag. J., vol. 15, no. 1, hlm. 1-12, Jan 2002.

[8] A. N. and, "Penyelenggaraan Pengukuran Kemiskinan Di Badan Pusat Statistik: Pendekatan Teori Jejaring-Aktor,” J. Sosioteknologi, vol. 17, no. 1, hlm. 154-170, Apr 2018.

[9] A. S. Dewi, "Metode-Metode Apa Saja Yang Digunakan Dalam Penelitian Media Sosial Untuk Kepentingan Bisnis?,” J. Pemikir. Sosiol., vol. 3, no. 1, hlm. 47, Jan 2016.

[10] rizky Natassia, "Pengaruh Gaya Kepemimpinan Dan Motivasi Kerja Terhadap Kinerja Karyawan Badan Pusat Statistik (BPS) Kota Padang," economica, vol. 2, no. 2, hlm. 134143, Jul 2015.

[11] K. S. Indraningsih, "Pengaruh Penyuluhan Terhadap Keputusan Petani dalam Adopsi Inovasi Teknologi Usahatani Terpadu," J. Agro Ekon., vol. 29, no. 1, hlm. 1, Agu 2016.

[12] H.-C. Shiau, "The Impact of Product Innovation on Behavior Intention: The Measurement of the Mediating Effect of the Brand Image of Japanese Anime Dolls," The Anthropologist, vol. 17, no. 3, hlm. 777-788, Mei 2014. 
